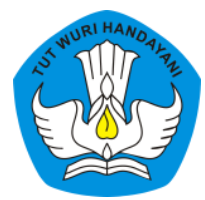

Page: 227-254

\title{
Guided Discovery Learning Menggunakan Tabel Andromatika untuk Meningkatkan Motivasi dan Hasil Belajar Matematika
}

\author{
Nurohim \\ Sekolah Dasar Negeri Kaliwlingi 02, Kabupaten Brebes, Jawa Barat \\ Contributor Email: nurohim.spd.sd@gmail.com
}

Published: Mar 30, 2020

Article Url: http:/ / ojsdikdas.kemdikbud.go.id/index.php/didaktika/article/view/157

\begin{abstract}
Learning outcomes that are not optimal can cause delays in further learning. The scovery learningresearch objective is to develop ICT-based learning media, namely the Andromatics Table which is applied to guided discovery learning, and to know its effects on increasing motivation, learning outcomes, and describing the characters developed in the implementation of Mathematics learning. The research uses the 4D (Four-D) model research and development method which includes define, design, develop, and disseminate. The results showed a significant increase in the motivation, learning outcomes, and character of IVB grade students at Kaliwlingi State Elementary School 02. Based on the ARCS questionnaire instrument, students' learning motivation increased by 26 stdents, which initially averraged less than average be very good. The learning outcomes of students whose initial percentage of mastery learning was only $38.46 \%$ while after the action percentage of completeness became $96.15 \%$ withn an average value of learning outcomes reaching 89,62. Mathematics KKM is 65. The character of students that increases after learning based on the PPK movement includes the value of slef-reliance, mutual cooperation value, and integrity values. The conclusion can be drawn that Guided Discovery Learning using the Andromatika Table has an impact on increasing motivation, learning outcomes, and developing students' character.
\end{abstract}

Keywords: Guided Discovery Learning, Andromatics Table, Motivation, Learning Outcomes, Students Character 


\begin{abstract}
Abstrak
Hasil pembelajaran yang belum optimal dapat menyebabkan terhambatnya pada pembelajaran selanjutnya. Tujuan penelitian untuk mengembangkan media pembelajaran berbasis TIK, yakni Tabel Andromatika yang diterapkan pada Guided Discovery Learning, dan mengetahui pengaruhnya bagi peningkatan motivasi, hasil belajar, serta mendeskripsikan karakter yang dikembangkan dalam pelaksanaan pembelajaran Matematika. Pelaksanaan penelitian menggunakan metode penelitian dan pengembangan model 4D (Four-D) yang meliputi Define, Design, Develop, dan Disseminate. Hasil penelitian menunjukkan adanya grafik peningkatan yang cukup signifikan pada motivasi, hasil belajar, serta karakter peserta didik kelas IVB SD Negeri Kaliwlingi 02. Berdasarkan instrumen angket ARCS, motivasi belajar peserta didik mengalami peningkatan yakni 26 peserta didik yang awalnya rata-rata berkategori kurang baik meningkat menjadi sangat baik. Hasil belajar peserta didik yang awal persentase ketuntasan belajarnya hanya 38,46\% sedangkan setelah tindakan persentase ketuntasan menjadi 96,15\% dengan nilai rata-rata hasil belajarnya mencapai 89,62. KKM pelajaran Matematika yaitu 65. Adapun karakter peserta didik yang meningkat setelah pembelajaran berdasarkan Gerakan PPK meliputi nilai mandiri, nilai gotong royong, dan nilai integritas. apat diambil kesimpulan bahwa Guided Discovery Learning menggunakan Tabel Andromatika berimbas pada peningkatan motivasi, hasil belajar, dan mengembangkan karakter peserta didik.
\end{abstract}

Kata Kunci: Guided Discovery Learning, Tabel Andromatika, Motivasi, Hasil Belajar, Karakter Peserta Didik

\title{
A. Pendahuluan
}

Permendikbud Nomor 22 tahun 2016 tentang Standar Proses Pendidikan Dasar dan Menengah menjelaskan bahwa kegiatan belajar mengajar dapat dilakukan melalui kegiatan yang memiliki rasa interaksi ataupun inspirasi, memiliki suasana yang senang dan penuh tantangan, memunculkan adanya pemberian semangat pada peserta didik supaya mampu berperan aktif sekaligus memberikan kesempatan seluas-luasnya untuk menuangkan ide, kreativitas dan sikap mandiri berdasarkan bakat dan minatnya serta perkembangan/pertumbuhan fisik maupun psikologis. Selain media pembelajaran, unsur lain yang mendukung keberhasilan dalam pembelajaran adalah penerapan model pembelajaran. Trianto (2010: 141) mengemukakan bahwa jika seorang guru mampu 
memilih dan menggunakan pendekatan, metode, maupun model pembelajaran yang tepat dapat menarik perhatian dan simpati peserta didik sehingga memungkinkan ia mampu untuk melaksanakan proses pembelajaran secara terarah, baik dan menyenangkan.

Kenyataannya, pembelajaran matematika yang berlangsung di sekolah tidak menyenangkan bagi peserta didik. Pelajaran matematika dikatakan sebagai momok bagi peserta didik karena sangat sulit apalagi berkaitan dengan ilmu hitung menghitung. Peserta didik cepat merasa bosan dengan pelajaran matematika. Peserta didik belajar satu jam pelajaran matematika bisa diibaratkan seperti belajar selama satu hari penuh. Mereka merasa bosan dan ingin cepat-cepat mengakhiri pelajaran matematika. Hal demikian terlihat pada pembelajaran peserta didik kelas IVB SDN Kaliwlingi 02 tahun pelajaran 2018/2019 pada materi FPB dan KPK. Hasil pembelajaran materi FPB dan KPK cenderung masih rendah. Selain itu, motivasi belajar peserta didik juga masih rendah.

Salah satu penyebabnya adalah guru tidak menerapkan dan mengembangkan media belajar sesuai dengan karakteristiknya. Penggunaan media belajar yang disampaikan oleh guru masih monoton dan belum menarik. Selain itu, media masih berbentuk manual sehingga peserta didik tidak memiliki rasa tantangan untuk belajar yang lebih menyenangkan. Padahal seharusnya di Era Industri 4.0 media pembelajaran diharapkan sudah mampu berbasis TIK sebagai bentuk realisasi menyongsong pendidikan yang lebih maju. Selain itu, model pembelajaran pun masih kurang menarik bagi peserta didik dalam pembelajaran. Guru masih menerapkan metode klasik dalam pembelajarannya, yakni ceramah dan tanya jawab. Hal ini menyebabkan munculnya kejenuhan dalam diri peserta didik dan pemahaman yang masih kurang jelas terhadap materi yang disampaikan oleh guru.

Perlu inovasi dalam pembelajaran yakni salah satunya dengan penggunaan media Tabel Andromatika yang dikolaborasikan dengan Guided Discovery Learning yang diharapkan mampu membawa pada 
peningkatan motivasi dan hasil belajar sebagai bentuk realisasi perwujudan Era Industri 4.0. Menurut Eggen dan Kauchak (2012: 177) bahwa Guided Discovery Learning adalah model belajar dan mengajar yang dalam pelaksanaannya segala contoh topik secara mendalam dan spesifik sekaligus memandunya untuk memahami berbagai macam konsep tertentu yang disampaikan oleh guru. Jadi, guru berfungsi sebagai fasilitator dalam pembelajaran sekaligus pembimbing bagi peserta didik agar ia mau menemukan konsep yang mereka anggap sebagai sesuatu yang baru.

Lebih lanjut Gatot Muhsetyo dkk (2009: 1.35) mengatakan bahwa Guided Discovery Learning merupakan model strategi pembelajaran dengan menggunakan alur langkah yang urut dan sistematis sehingga peserta didik mampu merasakan penemuan yang baru. Sebenarnya apa yang diperoleh peserta didik bukanlah temuan yang baru bagi guru, namun bagi peserta didik hal demikian merupakan sesuatu yang baru atau sebagai temuan yang baru. Menurut Markaban (2008: 22) beberapa kelebihan Guided Discovery Learning yaitu: (1) Keaktifan peserta didik lebih meningkat dalam pembelajaran karena ia secara mandiri berpikir dan menggunakan seluruh kemampuannya untuk mendapatkan hasil akhir yang lebih menantang; (2) Memberikan kesempatan seluas-luasnya untuk terlibat secara aktif hubungan antara peserta didik dengan guru; (3) Materi yang didapatkan oleh peserta didik lebih lama hilangnya dan mencapai kemampuan pengetahuan level tinggi karena peserta didik terlibat secara langsung dalam proses penemuan konsep; (4) Membantu peserta didik dalam pemecahan suatu masalah; (5) Peserta didik memahami materi dan konsep pembelajaran dengan baik karena ia melalui proses menemukan konsep dengan sendirinya; (6) Kepuasan dalam belajar sehingga mampu meningkatkan minat belajarnya; (7) Pengetahuan yang didapatkan melalui proses penemuan dapat mentransfer pengetahuannya ke berbagai konsep pengetahuan yang lainnya; (8) Peserta didik lebih banyak untuk belajar secara mandiri; dan (9) Pembelajaran akan terasa lebih bersemangat dan menyenangkan. 
Tabel Andromatika adalah media belajar berbasis android. Media ini berupa simulasi alat peraga FPB dan KPK yang berbentuk tabel atau atau permainan congklak yang dimodifikasi dan dikembangkan menjadi sebuah media yang mampu dioperasikan pada perangkat smartphone android. Adapun kelebihan media Tabel Andromatika yaitu praktis/sederhana dan mudah dibawa kemana saja, tidak membutuhkan ruang yang besar untuk menyimpannya, awet dan tahan lama, menghemat buku kertas dan pulpen.

Sharpless (dalam Ach. Reno Sya'roni dan Ria Amalia, 2016: 800) bahwa pembelajaran yang memanfaatkan penggunaan handphone atau smartphone sering disebut dengan istilah mobile learning. Dalam pembelajaran yang memanfaatkan media Tabel Andromatika, peserta didik tidak membutuhkan koneksi internet. Seperti pendapat yang dikemukakan oleh Georgiev (dalam Ach. Reno Sya'roni dan Ria Amalia, 2016: 801) bahwa pembelajaran berbasis mobile merupakan pembelajaran yang dilakukan di manapun dan kapanpun tanpa adanya koneksi fisik secara permanen yakni dengan jaringan kabel (cable network).

Sumiati dan Asra (2008: 59) menerangkan bahwa motivasi belajar merupakan suatu dorongan yang ada dalam diri peserta didik untuk melaksanakan/melakukan sesuatu hal yang berkaitan dengan timbulnya rasa dalam peserta didik untuk belajar. Perilaku belajar ini timbul dalam diri sendiri sehingga peserta didik tidak akan mudah menyerah ketika ia menemukan hal yang berkaitan dengan kesulitan dalam belajar, dan ketika ia menemukan materi dalam pembelajaran yang sulit/kurang paham, ia pun tetap memiliki motivasi tinggi untuk tetap belajar. Motivasi belajar memiliki peran yang sangat vital dalam keberhasilan pembelajaran peserta didik. Oleh karena itu, peneliti melakukan pengukuran motivasi belajar peserta didik dengan menggunakan instrumen angket ARCS yang dikemukakan oleh John Keller. Beliau mengemukakan 4 kondisi pengukuran motivasi belajar peserta didik, meliputi Atention, Relevance, Confidence, dan Satisfaction. 
Wahidmurni dkk (2010: 18) mengatakan bahwa jika seseorang/peserta didik sudah menunjukkan adanya perubahan perilaku belajar dalam dirinya, maka dapat dikatakan bahwa peserta didik sudah berhasil dalam pembelajaran. Begitu juga sebaliknya, jika peserta didik belum menunjukkan perubahan perilaku dalam belajar maka ia belum berhasil sehingga perlu adanya tindak lanjut seperti remidi. Perubahan perilaku peserta didik diantaranya dari segi kemampuan dalam berpikir (kognitif), keterampilan (psikomotor), dan sikap atau perilaku (afektif). Ketiga aspek tersebut merupakan satu kesatuan utuh hasil belajar yang saling berkaitan satu sama lain.

Gerakan Penguatan Pendidikan Karakter (PPK) adalah bentuk perwujudan Nawacita sekaligus sebagai Gerakan Revolusi Mental yang dijadikan sebagai poros utama dari pelaksanaan pendidikan sehingga terciptalah perubahan karakter bangsa menuju ke arah yang lebih baik. Gerakan PPK sebagai bentuk realisasi pada program pemerintah dalam pelaksanaan kebijakan yang termuat dalam Gerakan Nasional Pendidikan Karakter yang memiliki landasan pada kebijakan pemerintah berupa "RAN" (Rencana Aksi Nasional). Jadi, Gerakan PPK sebagai perwujudan keberlanjutan dan kesinambungan dari program pemerintah dalam pendidikan karakter (Kemdikbud, 2017: 5). Tujuan PPK adalah pembentukan generasi emas masa depan bangsa yang memiliki dan membudayakan nilai-nilai karakter yang kuat. Ada 5 (lima) nilai penting pembentuk karakter yang dirumuskan pemerintah dalam pendidikan karakter sekaligus sebagai prioritas dalam Gerakan PPK yaitu: religiusitas, nasionalisme, kemandirian, gotong royong, dan integritas (Kemdikbud, 2017:8).

Adapun tujuan pengembangan media pembelajaran di antaranya: (1) Mengetahui pengaruh pemanfaatan Tabel Andromatika yang diterapkan pada Guided Discovery Learning terhadap peningkatan motivasi belajar peserta didik; (2) Mengetahui pengaruh pemanfaatan Tabel Andromatika yang diterapkan pada Guided Discovery Learning terhadap peningkatan hasil belajar matematika materi FPB dan KPK; dan (3) Mendeskripsikan 
karakter peserta didik yang dapat dikembangkan setelah penggunaan Tabel Andromatika yang diterapkan pada Guided Discovery Learning materi FPB dan KPK.

Secara teoretis, hasil pengembangan media pembelajaran bermanfaat sebagai bahan acuan dan masukan dalam pelaksanaan pembelajaran pelajaran matematika pada materi FPB dan KPK serta wujud sumbangsih terciptanya media pembelajaran yang berbasis TIK yang dikolaborasikan dengan model pembelajaran sebagai upaya meningkatkan mutu pendidikan di Indonesia secara keseluruhan. Sedangkan secara praktis, hasil penelitian ini bermanfaat bagi peserta didik, guru, dan sekolah. Bagi peserta didik antara lain: dapat meningkatkan motivasi belajar pada peserta didik; peningkatan mutu hasil belajar pada pembelajaran matematika; dan dapat mengembangkan karakter peserta didik. Bagi guru yaitu: mengembangkan kemampuan bagi guru menciptakan media pembelajaran yang berbasis TIK pada pembelajaran matematika; memberikan penjelasan dan gambaran bagaimana rangkaian pembelajaran yang melibatkan peserta didik yang baik sehingga tercipta pembelajaran yang aktif, inovatif, kolaboratif, kreatif, enaktif, menyenangkan, dan berkarakter; dan dapat mendorong dan meningkatkan guru untuk berkreatifitas dalam pembelajaran di kelas.

Sedangkan bagi sekolah antara lain: sebagai sumber acuan dan bahan pertimbangan alternatif dalam pengembangan media dan model pembelajaran sehingga diharapkan mampu mendorong peningkatan kualitas pembelajaran; sebagai sumber referensi di sekolah dalam rangka pengembangan karya inovasi pembelajaran; dan sebagai acuan bahan pertimbangan dalam pengambilan kebijakan terutama program pembelajaran matematika di sekolah.

\section{B. Metode}

Rancangan karya inovasi pembelajaran difokuskan pada pemanfaatan Tabel Andromatika. Sedangkan penerapan media 
pembelajarannya mengacu pada sintaks model pembelajaran Guided Discovery Learning yang terdiri atas empat fase, yakni pendahuluan, openended phase, konvergen, penutup dan penerapan. Penerapan media Tabel Andromatika digunakan pada fase open-ended phase dan fase konvergen.

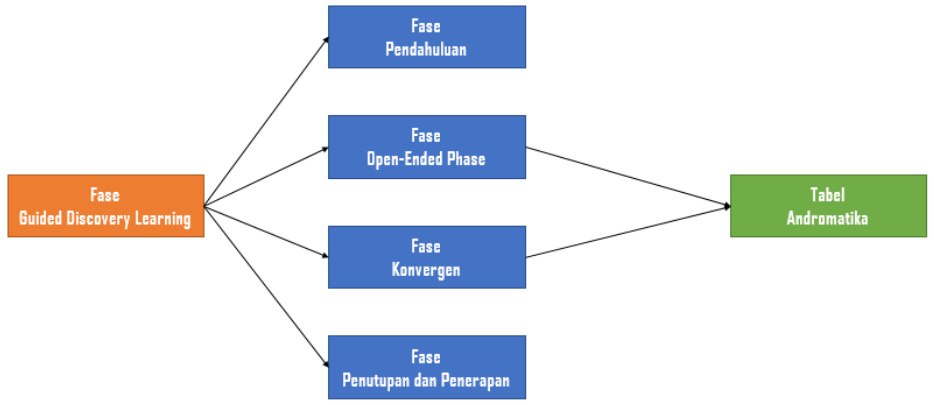

Gambar 1. Desain pembelajaran

\section{Rancangan Karya Inovasi Pembelajaran}

Pembuatan Tabel Andromatika menggunakan software pendukung berupa Construct 2. Software ini sangat familiar di kalangan para pembuat game/aplikasi berbasis android. Construct 2 dikeluarkan oleh perusahaan pengembang software yakni Scirra. Pada Construct 2 ada dua bagian penting yang harus diperhatikan, yakni layout dan evensheet. Layout sebagai tempat untuk memasukkan objek, baik berupa gambar, audio, maupun fungsi. Sedangkan evensheet digunakan sebagai tempat untuk pembuatan logika pemrograman. Artinya keterhubungan antara layout satu dengan yang lainnya menggunakan evensheet.

Adapun rancangan karya inovasi pembelajaran secara garis besar dapat digambarkan berikut ini:

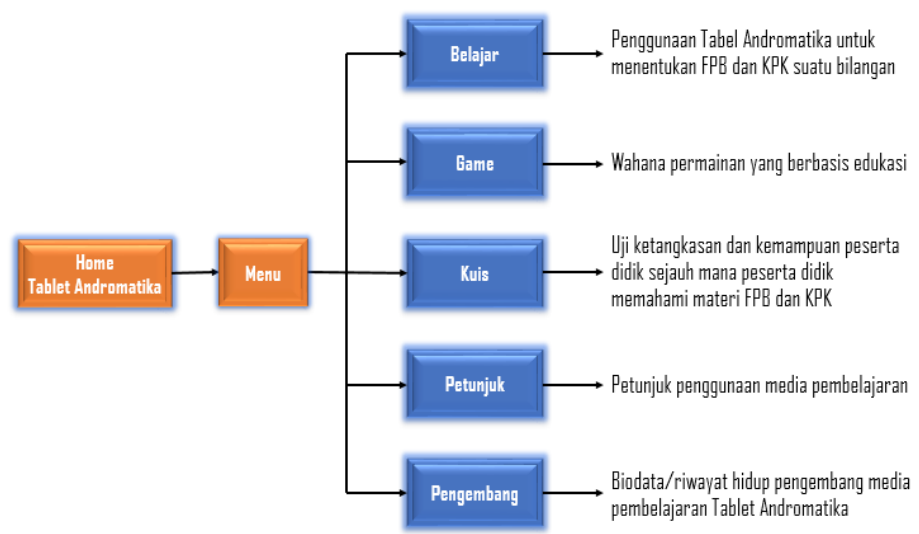

Gambar 2. Desain rancangan karya inovasi pembelajaran 
Nurohim

Penjelasan rancangan Tabel Andromatika sebagai berikut:

\section{Home}

Home merupakan layout halaman depan aplikasi Tabel Andromatika. Untuk masuk ke halaman menu, peserta didik harus mengklik objek/sprite button play. Sprite adalah gambar objek yang dimasukkan pada layout Construct 2.

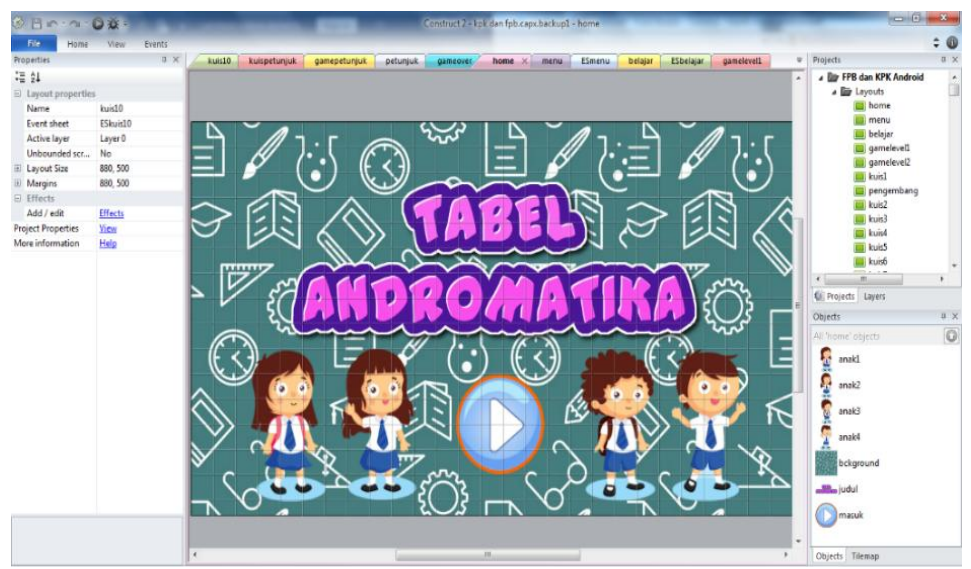

Gambar 3. Tampilan layout home

\section{Menu}

Pada layout menu ada beberapa objek/sprite yang bisa mengantarkan peserta didik ke layout yang akan dituju, diantaranya: menu belajar, menu game, menu kuis, menu petunjuk, dan menu pengembang. Pada layout menu juga disediakan button exit.

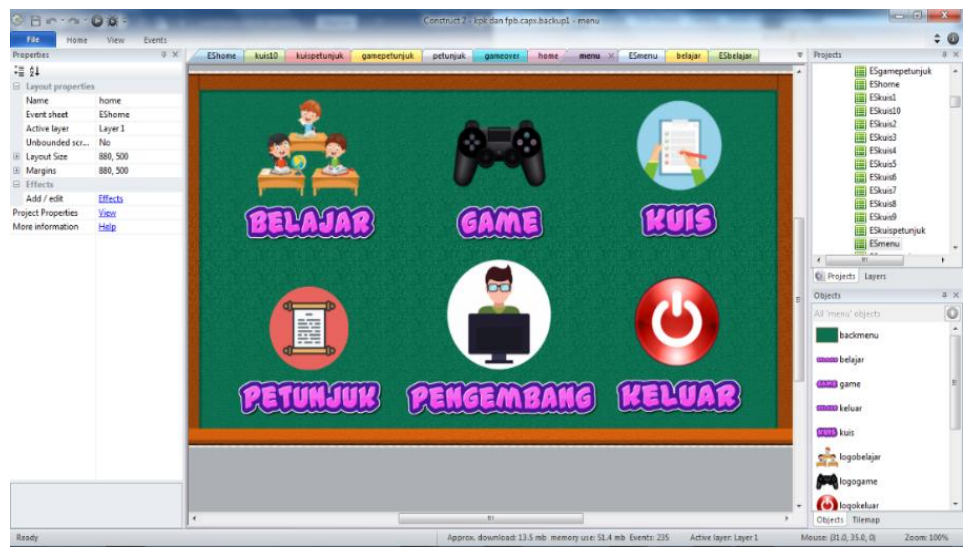

Gambar 4. Tampilan layout menu 


\section{Belajar}

Belajar merupakan layout utama yang berisi cara mensimulasikan dan menentukan FPB KPK suatu bilangan. Pada layout ini, peserta didik akan diajari cara menggunakan aplikasi Tabel Andromatika yakni dengan drag and drop pada objek bilangan ke tabel yang tersedia. Dengan demikian, peserta didik akan melakukan percobaan sekaligus penemuan terbimbing dalam menentukan FPB dan KPK suatu bilangan. Pada layout belajar, ada beberapa objek yang harus dipahami, yaitu:

a. Objek tabel, sebagai tempat untuk menyusun dan menentukan FPB dan KPK suatu bilangan.

b. Objek FPB, sebagai tempat hasil FPB suatu bilangan.

c. Objek KPK, sebagai tempat hasil KPK suatu bilangan.

d. Objek tong sampah, jika peserta didik mengkliknya maka seluruh aktivitas yang telah dilakukan maka akan hilang (hapus).

e. Objek bilangan (0-9) dan objek " $X$ ", sebagai objek yang akan didrag and drop ke tabel yang sudah tersedia sesuai dengan kebutuhan dalam menentukan FPB dan KPK suatu bilangan.

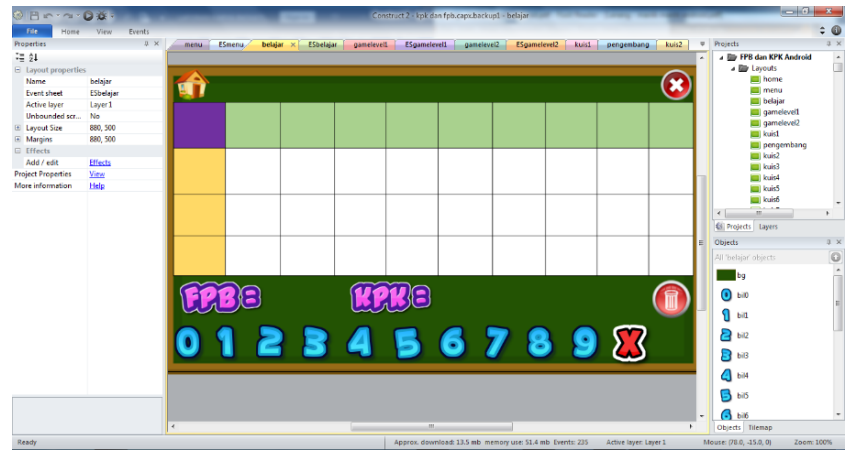

Gambar 5. Tampilan layout belajar

\section{Game}

Pada layout game, peneliti membuat game yang hampir mirip seperti permainan mario namun dengan sprite yang berbeda. Cara memainkannya pun mirip seperti permainan mario. Hal ini sebagai upaya agar peserta didik mampu memainkan aturan permainan ini sehingga tidak membingungkan pemain/peserta didik. Level pada game hanya 3 level, namun memiliki tingkat kesukaran yang berbeda dari mudah, sedang, dan sulit. 

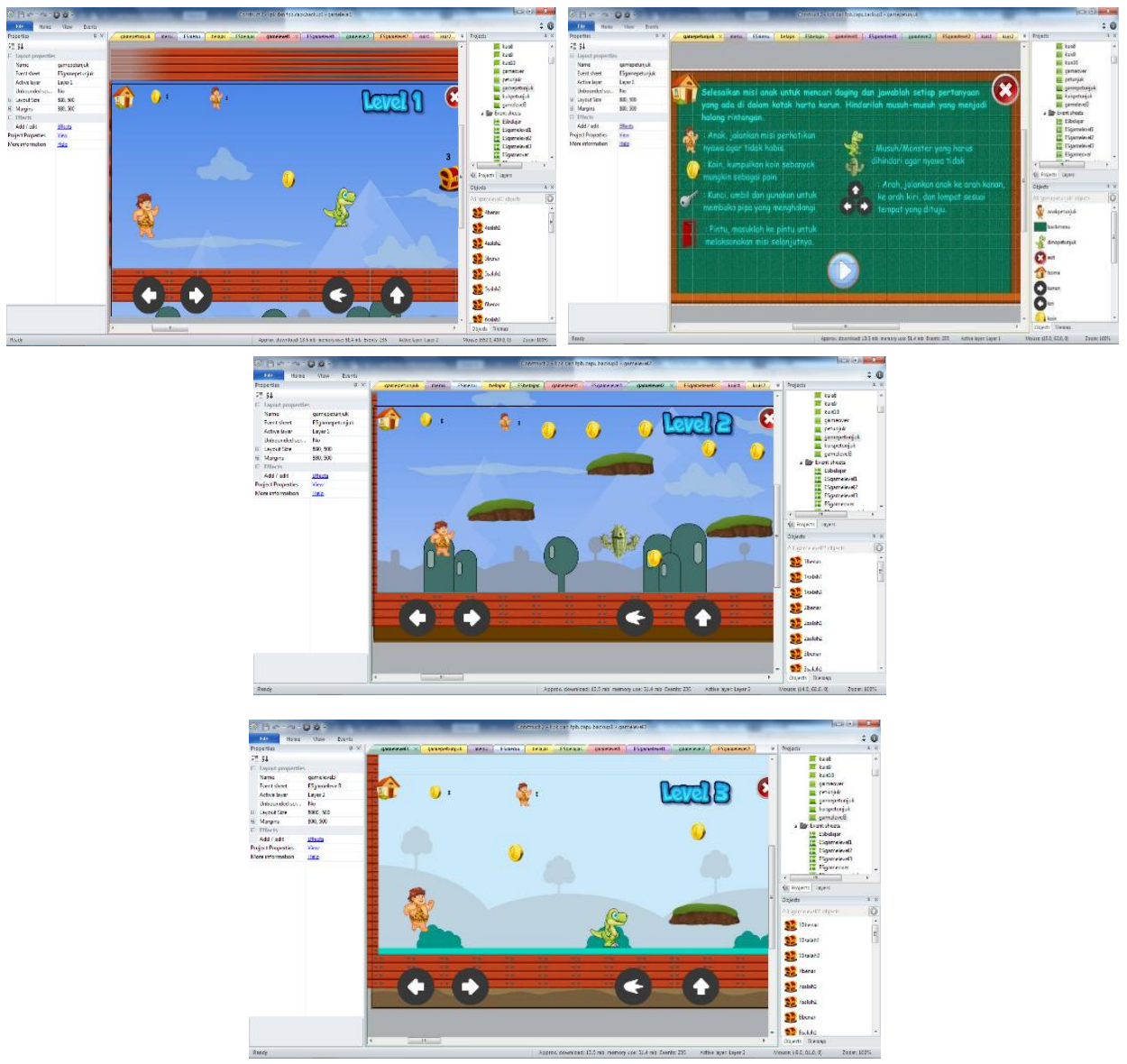

Gambar 6. Tampilan layout petunjuk game dan game edukasi

\section{Kuis}

Kuis merupakan layout pada aplikasi yang berfungsi untuk mengukur sejauhmana tingkat keberhasilan peserta didik dalam memahami materi FPB dan KPK setelah menggunakan media Tabel Andromatika. Pada kuis terdiri atas 10 soal, sedangkan setiap soal bernilai 10 jika menjawab dengan benar sehingga jika benar semua nilainya 100 . Pada layout kuis, peserta didik akan diberi soal dan menjawab dengan cara memilih jawaban yang benar dan akan muncul objek ketika jawaban benar maupun salah. Sehingga kuis ini bersifat interaktif. 


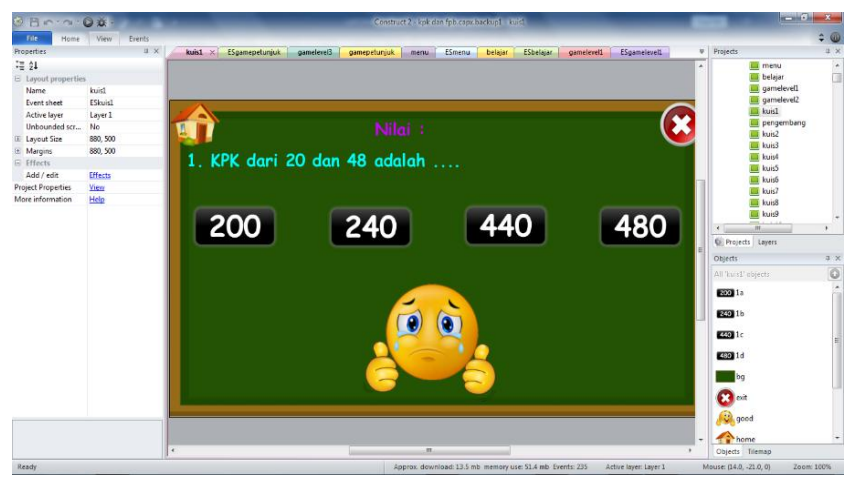

Gambar 7. Salah satu tampilan layout kuis

\section{Petunjuk}

Petunjuk merupakan layout yang berisi cara penggunaan aplikasi media Tabel Andromatika. Pada layout ini, peserta didik diberi arahan cara menggunakan aplikasi media ini melalui penjelasan singkat tiap menu sehingga bisa menghindari kesalahan ketika menggunakan media tersebut.

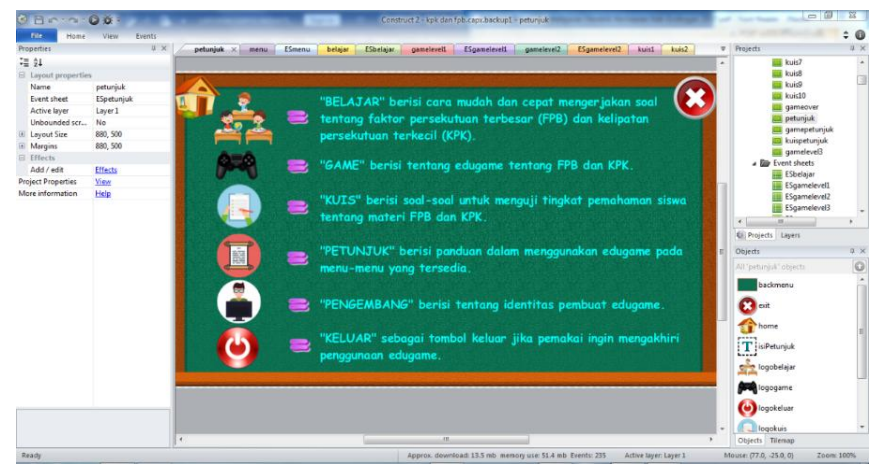

Gambar 8. Tampilan layout petunjuk

\section{Pengembang}

Pengembang merupakan layout identitas pengembang dari media Tablet Andromatika. Pada layout ini tercantum dari nama pengembang, alamat, sampai pada nomor handphone dan email yang bisa dihubungi ketika pengguna mengalami kesulitan dalam menggunakan Tablet Andromatika. 


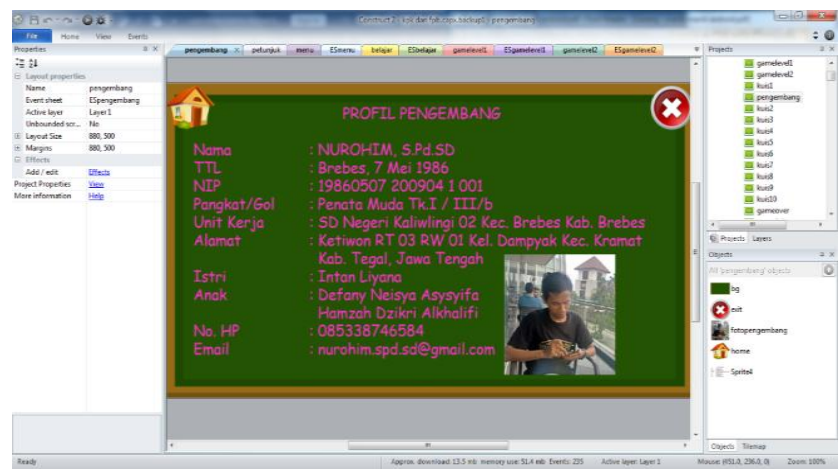

Gambar 9. Tampilan layout pengembang

\section{Proses Penemuan/Pembaharuan}

Adapun metode pengembangan karya inovasi pembelajaran yaitu menggunakan model pengembangan Four-D (4D) atau yang lebih dikenal model 4D. Adapun Model Four-D (4D) dikembangkan oleh Sivasailam Thiagarajan, Dorothy S. Semmel, dan Melvyn I. Semmel yakni sekitar tahun 1974. Menurut Thiagarajan, dkk (1974: 5) bahwa ada 4 tahap pengembangan dalam model penelitian dan pengembangan yang dikembangkannya, yakni Define, Design, Develop, dan Disseminate. Keempat tahapan pengembangan tersebut sering disebut Model 4-D.

\section{Pendefinisian (Define)}

Pada tahap ini peneliti mendefinisikan dan menentukan berbagai macam kebutuhan dalam proses pembelajaran serta mengumpulkan informasi penting yang diperlukan untuk pengembangan media. Ada lima langkah dalam tahap pendefinisian ini, meliputi:

a. Analisis awal (Front-End Analysis), yakni proses pembelajaran kurang optimal sehingga perlu pengembangan bahan ajar pembelajaran.

b. Analisis peserta didik (learner analysis), yaitu rendahnya pada hasil belajar dan motivasi belajar pada peserta didik.

c. Analisis tugas (task analysis), yaitu peneliti mengidentifikasi tugas peserta didik yang harus dicapai yakni pengetahuan dan keterampilan dalam menentukan FPB dan KPK suatu bilangan.

d. Analisis konsep (Concept Analysis), yaitu menentukan standar kompetensi dan kompetensi dasar pembelajaran matematika pada kelas 5. Adapun Kompetensi Dasar materi FPB dan KPK yaitu 3.6 menjelaskan dan menetukan faktor persekutuan, 
faktor persekutuan terbesar (FPB), kelipatan persekutuan terkecil (KPK) dari dua bilangan berkaitan dengan kehidupan sehari-hari serta 4.6 menyelesaikan masalah yang berkaitan dengan faktor persekutuan, faktor persekutuan terbesar, dan kelipatan persekutuan terkecil (KPK) dari dua bilangan berkaitan dengan kehidupan sehari-hari (Kemdikbud : 2013).

e. Merumuskan tujuan pembelajaran (Specifying Insructional Objectives) yakni untuk peningkatan motivasi belajar peserta didik dan hasil belajar materi FPB dan KPK melalui pemanfaatan media Tabel Andromatika dengan Guided Discovery Learning.

\section{Perancangan (Design)}

Pada tahap ini meliputi perancangan karya inovasi pembelajaran. Adapun tahap design ini mencakup empat langkah yang harus dilalui, yaitu:

a. Menyusun kriteria tes (Criterion-Test Construction), yaitu menyusun tes penilaian tertulis baik pada pengetahuan maupun keterampilan, dan tes mengukur motivasi belajar peserta didik melalui instrumen angket model ARCS yang dikemukakan oleh Jhon Keller (dalam Wirawan dkk, 2013: 5). Beliau mengemukakan tes pengukuran motivasi belajar peserta didik meliputi atention, relevance, confidence, dan satisfaction.

b. Memilih media pembelajaran (Media Selection), yaitu pemilihan media belajar mengajar menggunakan TIK dan berbasis android serta disesuaikan dengan karakteristik peserta didik dan materi, yakni dengan Tablet Andromatika.

c. Memilih format (Format Selection), yaitu dengan mengkolaborasikan antara Guided Discovery Learning dengan media pembelajaran Tablet Andromatika. Kolaborasi antara media dengan model pembelajaran diharapkan dapat menjadikan pembelajaran yang optimal.

d. Mendesain awal (Initial Design), yakni proses merancang media Tabel Andromatika. Proses ini sudah dibahas pada uraian sebelumnya.

\section{Pengembangan (Develop)}

Pengembangan (Develop) merupakan tahap yang dilakukan peneliti untuk menghasilkan media belajar mengajar yang sudah dikembangkan dan atas masukan ahli media dan ahli IT serta uji coba 
yang dilakukan pada beberapa peserta didik. Ada dua langkah penting yang peneliti lakukan dalam tahapan ini, yaitu:

a. Validasi oleh Ahli (Expert Appraisal)

Rancangan media pembelajaran yang sudah dibuat kemudian diuji validasinya. Uji validasi media Tabel Andromatika dilakukan oleh kepala sekolah dan rekan guru yang lebih berkompeten terutama yang berkaitan dengan isi materi pembelajaran, sedangkan uji validasi pada rancangan aplikasi dilakukan oleh ahli IT yang paham tentang Construct 2. Ada beberapa masukan dan saran yang diberikan oleh dua tim ahli tersebut yang kesemuanya sebagai maksud untuk perbaikan media Tabel Andromatika.

Tabel 1. Daftar revisi Tabel Andromatika sesuai masukan dan saran tim ahli

\begin{tabular}{|c|c|c|c|}
\hline No. & Sebelum revisi & Saran dan masukan & Setelah revisi \\
\hline 1. & $\begin{array}{l}\text { Tidak ada latihan } \\
\text { soal/kuis }\end{array}$ & $\begin{array}{l}\text { Berilah latihan } \\
\text { soal/kuis agar lebih } \\
\text { menarik }\end{array}$ & $\begin{array}{l}\text { Ada menu kuis untuk } \\
\text { mengukur } \\
\text { pemahaman materi. }\end{array}$ \\
\hline 2. & $\begin{array}{l}\text { Aplikasi hanya bisa } \\
\text { dioperasikan pada } \\
\text { smartphone android. }\end{array}$ & $\begin{array}{l}\text { Sebaiknya aplikasi bisa } \\
\text { diinstal pada semua } \\
\text { gadget yang dimiliki } \\
\text { oleh siswa }\end{array}$ & $\begin{array}{l}\text { Aplikasi } r \text { dibuat } \\
\text { dalam bentuk APK } \\
\text { untuk smartphone } \\
\text { android, dan format } \\
\text { HTML5 bagi yang } \\
\text { tidak suport } \\
\text { gadgetnya. }\end{array}$ \\
\hline 3. & $\begin{array}{l}\text { Tidak ada objek silang } \\
\text { pada menu belajar }\end{array}$ & $\begin{array}{l}\text { Usahakan jangan } \\
\text { dikosongkan pada tabel } \\
\text { yang tak terisi bilangan, } \\
\text { karena bisa } \\
\text { membingungkan } \\
\text { peserta didik. }\end{array}$ & $\begin{array}{l}\text { Ada objek silang } \\
\text { pada menu belajar } \\
\text { agar tidak } \\
\text { membingungkan } \\
\text { peserta didik dalam } \\
\text { pemakaian media. }\end{array}$ \\
\hline 4. & $\begin{array}{l}\text { Objek bilangan pada } \\
\text { menu belajar terlalu } \\
\text { kecil, susah didrog } \\
\text { and drop }\end{array}$ & $\begin{array}{l}\text { Usahakan objek } \\
\text { bilangan dapat terlihat } \\
\text { dengan baik. }\end{array}$ & $\begin{array}{lr}\text { Objek } & \text { bilangan } \\
\text { diganti } & \text { dengan } \\
\text { ukuran yang } & \text { lebih } \\
\text { proporsional. } & \end{array}$ \\
\hline 5. & $\begin{array}{l}\text { Tampilan pada HP } \\
\text { ada bagian ruang } \\
\text { yang masih } \\
\text { kosong/berwarna }\end{array}$ & $\begin{array}{l}\text { Sebaiknya dibuat full } \\
\text { layar pada HP }\end{array}$ & $\begin{array}{l}\text { Tampilan menjadi } \\
\text { lebih full pada layar } \\
\text { gadget }\end{array}$ \\
\hline
\end{tabular}




\begin{tabular}{|c|c|c|c|}
\hline & putih. & & \\
\hline 6. & $\begin{array}{l}\text { Menu petunjuk belum } \\
\text { menjelaskan secara } \\
\text { detail }\end{array}$ & $\begin{array}{lr}\text { Sebaiknya } & \text { menu } \\
\text { petunjuk berisi } & \text { cara } \\
\text { menggunakan } & \text { tiap } \\
\text { menu } & \end{array}$ & $\begin{array}{l}\text { Menu petunjuk berisi } \\
\text { tentang cara } \\
\text { menggunakan media } \\
\text { secara detail }\end{array}$ \\
\hline 7. & $\begin{array}{l}\text { Kontrol game agak } \\
\text { sulit dikendalikan }\end{array}$ & $\begin{array}{l}\text { Sebaiknya kontrol game } \\
\text { dimudahkan karena } \\
\text { ketika bermain agak } \\
\text { sulit untuk bergerak. }\end{array}$ & $\begin{array}{lr}\text { Button arah } & \text { dan } \\
\text { tembak pada } & \text { menu } \\
\text { game } & \text { sudah } \\
\text { diperbaiki } & \text { lebih } \\
\text { ringan } & \text { dengan } \\
\text { mengubah } & \\
\text { evensheetnya. } & \end{array}$ \\
\hline 8. & $\begin{array}{l}\text { Menu kuis belum ada } \\
\text { kunci jawaban }\end{array}$ & \begin{tabular}{lr} 
Sebaiknya pada menu & \multicolumn{1}{c}{ kuis disertai } \\
kunci \\
jawaban agar & siswa \\
lebih & mudah \\
mengetahui dalam & belajar terutama ketika \\
jawaban kurang tepat.
\end{tabular} & $\begin{array}{l}\text { Kunci jawaban sudah } \\
\text { diberikan tiap soal } \\
\text { sehingga peserta } \\
\text { didik mengetahui } \\
\text { benar atau salah } \\
\text { ketika ia menjawab } \\
\text { pertanyaan tersebut. }\end{array}$ \\
\hline 9. & $\begin{array}{l}\text { angka pada kuis } \\
\text { terlalu besar }\end{array}$ & 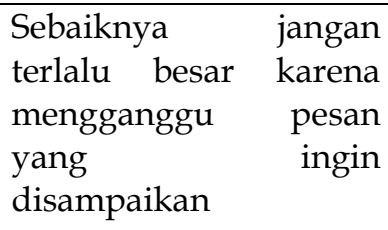 & $\begin{array}{lr}\text { Font } & \text { angka } \\
\text { disesuaikan dengan } \\
\text { tingkat kesesuaian } \\
\text { layout dengan font. }\end{array}$ \\
\hline 10. & $\begin{array}{lrr}\text { Font } & \text { angka } & \text { pada } \\
\text { menu } & \text { belajar } & \text { terlalu } \\
\text { kecil } & & \end{array}$ & $\begin{array}{lr}\text { Angka pada } & \text { menu } \\
\text { belajar terlalu } & \text { kecil } \\
\text { sehingga } & \text { susah } \\
\text { dipindahkan. } & \end{array}$ & $\begin{array}{lr}\text { Font } & \text { angka } \\
\text { berukuran } & \text { sedang } \\
\text { sehingga } & \text { sesuai } \\
\text { dengan } & \text { tampilan } \\
\text { layout. } & \end{array}$ \\
\hline
\end{tabular}

b. Uji coba Media Pengembangan (Developmental Testing)

Peneliti melakukan uji coba media belajar yang telah dikembangkan sebagai langkah untuk mendapatkan masukan berupa kritik dan saran agar dapat diperbaiki menjadi media pembelajaran yang lebih baik lagi. Uji coba dilakukan pada beberapa kelompok peserta didik lainnya kemudian beberapa masukan dari peserta didik sebagai penyempurnaan. Hal ini sebagai langkah masukan respon dari peserta didik sebelum digunakan dalam pembelajaran. Adapun hasil uji coba pada peserta didik dapat dilihat pada tabel 2 . 
Nurohim

Tabel 2. Hasil uji coba Tabel Andromatika pada kelompok peserta didik

\begin{tabular}{|c|c|c|c|c|c|}
\hline \multirow[b]{2}{*}{ No. } & \multirow{2}{*}{$\begin{array}{c}\text { Kelompok } \\
\text { Peserta Didik }\end{array}$} & \multicolumn{3}{|c|}{ Tingkat Kepuasan Peseta Didik } & \multirow{2}{*}{$\begin{array}{c}\text { Jumlah } \\
\text { Peserta } \\
\text { Didik }\end{array}$} \\
\hline & & $\begin{array}{c}\text { Tidak } \\
\text { Senang }\end{array}$ & Senang & $\begin{array}{l}\text { Sangat } \\
\text { Senang }\end{array}$ & \\
\hline 1. & Kelompok 1 & - & 2 & 3 & 5 \\
\hline 2. & Kelompok 2 & - & 1 & 4 & 5 \\
\hline 3. & Kelompok 3 & 1 & 1 & 3 & 5 \\
\hline
\end{tabular}

Hasil uji coba peenggunaan Tabel Andromatika pada beberapa kelompok siswa, menunjukkan hasil yang variatif. Mereka memiliki alasan tersendiri dalam menilai media tersebut. Kebanyakan dari peserta didik merasa sangat senang menggunakan media Tabel Andromatika. Disamping karena lebih efektif dan efisien, mereka merasa lebih mudah menggunakan media tersebut daripada yang manual karena membutuhkan waktu dan terlalu monoton. Mereka juga menikmati kuis yang disediakan karena lebih interaktif dan hasil nilai akhirnya bisa muncul secara langsung. Selain itu juga tersedia game edukasi yang berkaitan dengan FPB dan KPK. Sedangkan pada kategori senang karena mereka merasa seperti bermain gadget, padahal sebenarnya sedang menggunakan gadget untuk belajar tentang FPB dan KPK. Namun ada hal unik dari penilaian peserta didik, yakni satu peserta didik merasa tidak senang. Ia merasa kesulitan karena tidak bisa menggunakan gadget dengan baik (masih merasa kaku ketika menyentuh touchscreen).

Setelah peneliti melaksanakan uji coba media, langkah selanjutnya adalah perbaikan dari beberapa masukan yang diterima oleh peneliti. Setelah revisi selesai, media Tabel Andromatika siap digunakan dalam pembelajaran di kelas.

\section{Penyebaran (Disseminate)}

Tahap terakhir yaitu mendiseminasikan hasil media yang telah disempurnakan. Diseminasi sebagai wahana penyebarluasan hasil karya 
inovasi bagi rekan guru dan peserta didik lain sehingga pemanfaatan media lebih optimal bagi pendidikan. Diseminasi dilakukan pada lingkungan sekolah dan rekan guru di SDN Kaliwlingi 02 dan pada KKG gugus Soewardi Soeryaningrat.

Kelebihan sekaligus pembaharuan dari media Tabel Andromatika adalah media ini membantu siswa lebih menghemat dalam penggunaan kertas dan pulpen. Selain itu, media ini mampu mengarahkan peserta didik untuk belajar menggunakan HP berbasis android untuk kegiatan pembelajaran yang lebih bermanfaat. Sehingga peserta didik terbentuk pemikiran bahwa sesungguhnya HP berbasis android bisa digunakan untuk membantunya dalam pembelajaran. Pada sisi keefektifan, media ini juga membantu peserta didik untuk mempercepat dalam mengerjakan soal tentang FPB dan KPK. Hal ini bisa dilihat ketika peserta didik menggunakan cara manual tanpa bantuan HP berbasis android, ia membutuhkan waktu lebih lama dibandingkan dengan menggunakan media Tabel Andromatika. Pembaharuan lain dari media Tabel Andromatika adalah memadukan media pembelajaran dengan game edukatif. Pada menu game, peserta didik tidak hanya sekedar bermain dan bersenang-senang saja melainkan ada unsur pembelajaran karena harus memilih jawaban yang sesuai agar mendapatkan poin game yang tinggi. Untuk lebih jelasnya pembaharuan pada media lainnya bisa perhatikan pada tabel 3.

Tabel 3. Pembaharuan media Tabel Andromatika

\begin{tabular}{|c|l|l|l|}
\hline No & \multicolumn{1}{|c|}{$\begin{array}{c}\text { Unsur } \\
\text { Pembeda }\end{array}$} & \multicolumn{1}{|c|}{ Media Konvensional } & \multicolumn{1}{|c|}{ Tabel Andromatika } \\
\hline 1 & $\begin{array}{l}\text { Alat utama } \\
\text { media }\end{array}$ & $\begin{array}{l}\text { Menggunakan kertas } \\
\text { dan ballpoint sebagai } \\
\text { alat tulis }\end{array}$ & $\begin{array}{l}\text { Menggunakan gadget } \\
\text { HP android }\end{array}$ \\
\hline 2 & $\begin{array}{l}\text { Efektifitas } \\
\text { pemakaian }\end{array}$ & $\begin{array}{l}\text { Tidak efektif. Terlalu } \\
\text { banyak coretan/langkah } \\
\text { sehingga muncul } \\
\text { kejenuhan pada peserta } \\
\text { didik. Apalagi ketika } \\
\text { keliru dalam } \\
\text { penyelesaian maka }\end{array}$ & $\begin{array}{l}\text { Menggunakan cara "drag } \\
\text { and drop" sehingga } \\
\text { terlihat lebih menarik } \\
\text { perhatian peserta didik. } \\
\text { Ketika terjadi kekeliruan } \\
\text { dalam penyelesaian, } \\
\text { cukup klik ikon "tong }\end{array}$ \\
\hline
\end{tabular}


Nurohim

\begin{tabular}{|c|l|l|l|}
\hline 3 & Game edukasi & $\begin{array}{l}\text { tambah lebih tidak rapi } \\
\text { (buku) }\end{array}$ & $\begin{array}{l}\text { Tidak tersedia fitur game } \\
\text { edukasi } \\
\text { akan bersih kembali. }\end{array}$ \\
\hline 4 & Kuis & $\begin{array}{l}\text { Memuat fitur game } \\
\text { edukasi (bermain sambil } \\
\text { belajar) }\end{array}$ \\
\hline 5 & $\begin{array}{l}\text { Bentak tersedia kuis } \\
\text { sola/evaluasi }\end{array}$ & $\begin{array}{l}\text { Adanya fitur kuis } \\
\text { soal/evaluasi yang lebih } \\
\text { interaktif sehingga } \\
\text { peserta didik lebih aktif } \\
\text { dalam belajar }\end{array}$ \\
\hline 6 & $\begin{array}{l}\text { Bahan } \\
\text { pembuatan }\end{array}$ & $\begin{array}{l}\text { Lebih besar sehingga } \\
\text { sulit untuk dibawa } \\
\text { kemana saja }\end{array}$ & $\begin{array}{l}\text { Berupa aplikasi android } \\
\text { sehingga cukup instal } \\
\text { pada gadget android } \\
\text { dan sangat praktis untuk } \\
\text { dibawa kemana saja. }\end{array}$ \\
\hline $\begin{array}{l}\text { Menggunakan triplek } \\
\text { atau bahan lainnya } \\
\text { sehingga membutuhkan } \\
\text { banyak biaya. }\end{array}$ & $\begin{array}{l}\text { Proses pembuatan hanya } \\
\text { dengan laptop yang } \\
\text { sudah terinstal } \\
\text { Construct2, sehingga } \\
\text { minim biaya bahkan } \\
\text { tanpa biaya sama sekali. }\end{array}$ \\
\hline
\end{tabular}

\section{Hasil dan Pembahasan}

\section{Aplikasi Praktis dalam Pembelajaran}

Adapun mekanisme penerapan Tabel Andromatika dalam proses pembelajaran dikolaborasikan dengan Guided Discovery Learning. Langkah pembelajaran pemanfaatan media Tabel Andromatika disesuaikan dengan sintaks Guided Discovery Learning yakni melalui 4 fase yang akan dijelaskan sebagai berikut.

\section{a. Fase Pendahuluan}

Sebelum proses pembelajaran dimulai, peserta didik memasang aplikasi Tabel Andromatika pada smartphone yang telah dibawanya. Smartphone yang dibawa juga atas ijin dari orang tua dan kepala sekolah sebagai antisipasi terjadi sesuatu hal yang tidak diinginkan. Dari 26 peserta didik yang membawa smartphone android sebanyak 20 peserta didik sedangkan 6 peserta didik lainnya tidak membawa karena tidak dibolehkan oleh orang tuanya. Ketika proses pemasangan aplikasi, guru bertindak sebagai pembimbing sekaligus membantu untuk penginstalan aplikasinya pada perangkat android peserta didik. 
Setelah proses pemasangan aplikasi pada smartphone telah selesai, proses pembelajaran pun dimulai dengan kegiatan apersepsi. Peserta didik diajak bermain lompatan kecil seperti kodok dengan acuan jumlah keramik. Peserta didik yang pertama melompat dengan 2 keramik sekali lompatan sedangkan peserta didik yang kedua melompat dengan 3 keramik sekali lompatan. Maka kedua peserta didik akan bertemu pada keramik yang ke berapa. Biarkan peserta didik menebak sendiri sehingga apersepsi berjalan dengan menarik. Kemudian dilanjutkan lompatan 3 keramik dengan 4 keramik. Selain apersepsi, guru juga menyampaikan tujuan pembelajaran pada peserta didik. Hal ini sangat penting agar peserta didik dapat fokus pada pembelajaran yang berlangsung di kelas.

b. Fase Berujung-Terbuka (Open-Ended Phase)

Pada fase ini guru menjelaskan materi tentang FPB dan KPK secara singkat. Kemudian guru memperkenalkan dan menjelaskan petunjuk penggunaan Tabel Andromatika pada peserta didik dengan bantuan LCD proyektor. Hal ini bertujuan agar seluruh peserta didik dapat memahami cara penggunaan aplikasi tersebut sehingga tidak terjadi kekeliruan dalam pemakaian media Tabel Andromatika.

Untuk memastikan pemahaman peserta didik, guru memberikan contoh penggunaan media Tabel Andromatika. Peserta didik pun sambil melakukan contoh yang diberikan oleh guru untuk melatih psikomotor peserta didik sekaligus kemampuan peserta didik dalam menggunakan media Tabel Andromatika. Kemudian guru membentuk kelompok kecil yang heterogen dalam kemampuan akademiknya. Hal ini bertujuan agar pemerataan dalam kelompok sekaligus bisa menjadi tutor sebaya dalam pembelajaran.

\section{c. Fase Konvergen}

Pada fase ini peserta didik mulai mengerjakan LKS yang sebelumnya telah dibagi oleh guru. Peserta didik didorong agar mau menemukan hal yang baru dalam pembelajaran FPB dan KPK melalui media Tabel Andromatika. Guru berkeliling untuk membimbing peserta didik secara merata tanpa ada perbedaan berat sebelah. Peserta didik yang kurang memahami materi dan media pembelajaran, mendapat perhatian khusus dibandingkan peserta didik lain yang sudah memahaminya. Untuk kelompok yang telah selesai mengerjakan LKS, yakni bagi peserta didik yang sudah mahir dalam menggunakan media Tabel Andromatika diberi tantangan untuk membuat soal sendiri dan dijawab oleh peserta didik tersebut. Kemudian hasilnya dikonsultasikan dengan guru untuk memastikan benar atau salah dalam menentukan FPB dan KPK. 
Proses penemuan terbimbing sangat menarik terutama bagi peserta didik yang sudah memahami cara menggunakan media Tabel Andromatika. Mereka berlomba-lomba dalam mengerjakan soal tentang FPB dan KPK dengan media Tabel Andromatika. Bahkan beberapa peserta didik yang saling adu kecepatan dalam menentukan FPB dan KPK suatu bilangan, kemudian dikonsultasikan pada guru untuk mengecek kebenaran jawabannya.

Hasil pekerjaan LKS yang dilaksanakan peserta didik kemudian dibahas bersama-sama. Tiap kelompok menyampaikan hasil dari pekerjaannya. Ketika ada kekeliruan dalam pengisian LKS, guru segera meluruskan dan memberi masukan agar tiap kelompok memiliki persepsi dan konsep yang sama.

Langkah selanjutnya bermain kuis yang sudah tersedia pada aplikasi Tabel Andromatika. Permainan dilakukan per kelompok. Terbaik dari tiap kelompok kemudian diikutkan final. Hal demikian sebagai wujud pembelajaran yang menyenangkan dan interaktif sekaligus untuk mengukur kejujuran peserta didik dalam bersikap sehari-sehari. Setelah permainan kuis, dilanjutkan dengan game seperti pada game mario. Namun, tantangan berupa menjawab setiap pertanyaan yang dilewati oleh pemain. Skor tertinggi pemain adalah pemenang game.

\section{d. Fase Penutup dan Penerapan}

Peserta didik diajak untuk menyimpulkan materi pembelajaran yang telah dilaksanakan secara bersama-sama dengan bimbingan guru. Guru memberi kesempatan seluas-luasnya kepada para peserta didik untuk saling tanya jawab satu sama lain yang berkaitan dengan pemanfaatan media Tabel Andromatika. Setelah semuanya tidak mengalami kendala, kemudian dilanjutkan dengan memberikan penilaian. Guru memberikan soal evaluasi/penilaian secara klasikal dengan menggunakan media Tabel Andromatika.

\section{Hasil Inovasi yang Relevan}

Hasil penelitian dan pengembangan dari I Gusti Lanang Gede Putra Astawa yang berjudul "Pembelajaran Temuan Terbimbing Berbantuan Manik Android: Motivasi dan Hasil Belajar Operasi Hitung Bilangan Bulat" yang dimuat dalam Jurnal Didaktika Pendidikan Dasar Volume 2 Nomor 2 Tahun 2018. Adapun hasil penelitiannya bahwa pembelajaran temuan terbimbing berbantuan Manik Android dapat berimbas pada peningkatan motivasi belajar maupun hasil belajar operasi hitung bilangan bulat. Hal ini terbukti pada 35 peserta didik di kelas VI, 
dengan menggunakan instrumen angket ARCS dihasilkan rata-rata kondisi perhatian menjadi 4,6 berkategori sangat baik, kondisi relevansi rata-rata 4,1 dengan kategori baik, kondisi percaya diri rata-rata 4,6 berkategori sangat baik, dan kondisi kepuasan rata-rata 4,6 berkategori sangat baik. Selain itu, hasil belajar peserta didik mengalami peningkatan dengan rata-rata kelas mencapai 80,0 sedangkan dalam hal ketuntasan belajar peserta didik mencapai $88,57 \%$.

\section{Motivasi Belajar}

Pada pengembangannya, peneliti mengukur motivasi belajar peserta didik dengan menggunakan angket model ARCS dari Jhon Keller (dalam Wirawan dkk, 2013: 5). Angket ARCS berisi 36 pertanyaan yang harus diisi 26 peserta didik kelas 4B. Adapun hasil angket ARCS terhadap motivasi peserta didik dapat dilihat pada tabel 4.

Tabel 4 Data hasil motivasi belajar peserta didik kelas IV

\begin{tabular}{|c|c|c|c|c|c|c|}
\hline \multirow[t]{2}{*}{ No. } & \multirow[t]{2}{*}{ Kondisi } & \multicolumn{2}{|c|}{ Angket Motivasi } & \multirow{2}{*}{$\begin{array}{c}\text { Skor } \\
\text { Angket }\end{array}$} & \multirow{2}{*}{$\begin{array}{l}\text { Rata- } \\
\text { rata }\end{array}$} & \multirow[t]{2}{*}{ Kriteria } \\
\hline & & $\begin{array}{c}\text { Nomor } \\
\text { Pertanyaan } \\
\text { Positif }\end{array}$ & $\begin{array}{c}\text { Nomor } \\
\text { Pertanyaan } \\
\text { Negatif }\end{array}$ & & & \\
\hline 1 & $\begin{array}{l}\text { Perhatian } \\
\text { (Attention) }\end{array}$ & $\begin{array}{l}2,8,9,11,17 \\
20,23,24,28\end{array}$ & $12,15,22,29$ & 1596 & 4,72 & $\begin{array}{c}\text { Sangat } \\
\text { Baik }\end{array}$ \\
\hline 2 & $\begin{array}{c}\text { Relevansi } \\
\text { (Relevance) }\end{array}$ & $\begin{array}{c}4,6,16,18 \\
30,33\end{array}$ & 26,31 & 913 & 4,39 & Baik \\
\hline 3 & $\begin{array}{l}\text { Percaya Diri } \\
\text { (Confidence) }\end{array}$ & $1,13,25,35$ & $3,7,19$ & 839 & 4,61 & $\begin{array}{c}\text { Sangat } \\
\text { Baik }\end{array}$ \\
\hline 4 & $\begin{array}{c}\text { Kepuasan } \\
\text { (Statisfaction) }\end{array}$ & $\begin{array}{c}5,10,14,21 \\
27,32,36\end{array}$ & 34 & 998 & 4,80 & $\begin{array}{c}\text { Sangat } \\
\text { Baik }\end{array}$ \\
\hline \multicolumn{5}{|c|}{ Rata-rata } & 4,63 & $\begin{array}{c}\text { Sangat } \\
\text { Baik }\end{array}$ \\
\hline
\end{tabular}

Menilik hasil angket ARCS terhadap motivasi belajar peserta didik dapat diambil kesimpulan bahwa pemanfaatan Tabel Andromatika yang diterapkan pada Guided Discovery Learning dapat berimbas pada peningkatan motivasi belajar peserta didik. Hal demikian terlihat pada hasil angket tersebut yang menjelaskan bahwa motivasi belajar peserta didik pada rentang nilai rata-rata 4,63 yakni berkategori sangat baik dengan rincian kondisi perhatian, percaya diri, dan kepuasan berkategori sangat baik sedangkan kondisi relevansi berkategori baik. Penggunaan 
media pembelajaran yang menarik, memotivasi dan menantang peserta didik akan memiliki dampak yang baik terhadap motivasi belajar. Peningkatan terlihat pada motivasi belajarnya pada pembelajaran matematika materi FPB dan KPK. Peningkatan motivasi belajar sesuai dengan apa yang dikemukakan oleh Yazdani dan Godbole (2014: 829) yakni bahwa peserta didik yang memiliki motivasi dan semangat belajar yang baik akan menunjukkan aktivitas untuk berusaha keras walaupun ia menghadapi hambatan dan permasalahan dalam belajar, namun ia pantang menyerah. Adapun usaha keras yang dimaksud adalah usaha dalam bentuk fisik dan mental, serta bersungguh-sungguh dalam meraih prestasi.

\section{Hasil Belajar}

Adapun hasil belajar peserta didik kelas IV SDN Kaliwlingi 02 setelah pemanfaatan Tabel Andromatika yang diterapkan pada Guided Discovery Learningterlihat pada tabel5.

Tabel 5Data analisis hasil belajar peserta didik

\begin{tabular}{|c|c|c|c|c|}
\hline \multirow[t]{2}{*}{ No. } & \multirow[t]{2}{*}{ Rentang Nilai } & \multirow{2}{*}{$\begin{array}{c}\text { Banyak } \\
\text { Peserta Didik }\end{array}$} & \multicolumn{2}{|c|}{ Ketuntasan } \\
\hline & & & Tuntas & Tidak Tuntas \\
\hline 1. & $0-10$ & - & - & - \\
\hline 2. & $11-20$ & - & - & - \\
\hline 3. & $21-30$ & - & - & - \\
\hline 4. & $31-40$ & 1 & - & Tidak tuntas \\
\hline 5. & $41-50$ & - & - & - \\
\hline 6. & $51-60$ & - & - & - \\
\hline 7. & $61-70$ & 3 & Tuntas & - \\
\hline 8. & $71-80$ & 1 & Tuntas & - \\
\hline 9. & $81-90$ & 7 & Tuntas & - \\
\hline 10. & $91-100$ & 14 & Tuntas & - \\
\hline \multicolumn{2}{|c|}{ Jumlah Peserta didik } & \multicolumn{3}{|c|}{26} \\
\hline \multicolumn{2}{|c|}{ Nilai Tertinggi } & \multicolumn{3}{|c|}{100} \\
\hline \multicolumn{2}{|c|}{ Nilai Terendah } & \multicolumn{3}{|c|}{40} \\
\hline
\end{tabular}




\begin{tabular}{|c|c|c|c|c|}
\hline \multirow{2}{*}{ No. } & Rentang Nilai & Banyak & \multicolumn{2}{|c|}{ Ketuntasan } \\
\cline { 3 - 4 } & & Peserta Didik & Tuntas & Tidak Tuntas \\
\hline \multicolumn{2}{|c|}{ Rerata } & \multicolumn{3}{|c|}{89,62} \\
\hline \multicolumn{2}{|c|}{ Persentase Ketuntasan } & \multicolumn{3}{|c|}{$95 \%$} \\
\hline
\end{tabular}

Dapat disimpulkan bahwa ketuntasan belajar setelah pemanfaatan Tabel Andromatika yang diterapkan pada Guided Discovery Learning sangat tinggi yakni mencapai $96,15 \%$ atau dari 26 peserta didik yang sudah mampu sampai tuntas KKM mencapai 25 peserta didik sedangkan yang belum mencapai ketuntasan belajar hanya 1 peserta didik. Adapun KKM belajar FPB dan KPK adalah 65. Aktivitas belajar yang mencakup ranah afektif, kognitif, dan psikomotor melalui pemanfaatan Tabel Andromatika yang diterapkan pada Guided Discovery Learning dapat berimbas pada peningkatan hasil belajar peserta didik. Perihal mengenai hasil belajar selaras dengan yang dikemukakan oleh Rusman (2012: 123) yang menyampaikan bahwa sesungguhnya hasil belajar merupakan pengalaman unik dan baru yang didapatkan oleh peserta didik melalui kegiatan aktivitas belajar yang mencakup tiga ranah hasil belajar (ranah afektif, ranah kognitif, dan ranah psikomotor).

\section{Penguatan Pendidikan Karakter}

Adapun beberapa penguatan karakter yang terlihat pada peserta didik selama berlangsung proses pembelajaran tercantum dalam tabel 6 . Tabel 6. Deskripsi penguatan karakter yang dikembangkan dalam pembelajaran

\begin{tabular}{|c|l|l|}
\hline No & Nilai Karakter & \multicolumn{1}{|c|}{ Aktivitas yang Terlihat } \\
\hline 1 & Kemandirian & $\begin{array}{l}\text { Percaya diri, berani melakukan percobaan, } \\
\text { pantang menyerah sampai memahami materi, } \\
\text { berani, dan kreatif dalam belajar. }\end{array}$ \\
\hline 2 & Gotong royong & $\begin{array}{l}\text { Saling membantu dengan temannya, bersikap } \\
\text { empati, rela menolong teman yang belum } \\
\text { memahami materi, berkerja sama, saling } \\
\text { menghargai satu sama lain. }\end{array}$ \\
\hline 3 & Integritas & $\begin{array}{l}\text { Jujur dalam bermain kuis, komitmen terhadap } \\
\text { keputusan bersama, bertanggung jawab, adil } \\
\text { terhadap sesama teman. }\end{array}$ \\
\hline
\end{tabular}


Pelaksanaan pembelajaran melalui Guided Discovery Learning menggunakan Tabel Andromatika juga mampu mengembangkan karakter peserta didik, yakni mandiri, gotong royong, dan integritas. Nilai karakter peserta didik muncul seiring dengan berlangsungnya pembelajaran. Munculnya karakter yang baik selaras dengan apa yang diinformasikan dalam kemdikbud (2017: 13) yakni pelaksanaan penguatan pendidikan karakter melalui integrasi dalam mata pelajaran berdasarkan rencana pelaksanaan pembelajaran yang sistematis.

Peneliti juga mengumpulkan data mengenai tingkat kepuasan peserta didik terhadap penggunaan media Tabel Andromatika. Tingkat kepuasan peserta didik terhadap media Tabel Andromatika tercantum dalam tabel 7.

Tabel 7. Data tingkat kepuasan peserta didik terhadap Tabel Andromatika

\begin{tabular}{|c|l|c|c|}
\hline No. & $\begin{array}{c}\text { Tingkat Kepuasan Peserta } \\
\text { Didik }\end{array}$ & $\begin{array}{c}\text { Jumlah Peserta } \\
\text { Didik }\end{array}$ & Persentase \\
\hline 1. & Tidak senang & 2 & $7,7 \%$ \\
\hline 2. & Senang & 6 & $23,1 \%$ \\
\hline 3. & Sangat Senang & 18 & $69,2 \%$ \\
\hline \multicolumn{2}{r|}{ Jumlah } & 26 & $100 \%$ \\
\hline
\end{tabular}

Penerapan Media Tabel Andromatika juga diukur pada tingkat kepuasan peserta didik dalam menggunakan media tersebut. Sebagian besar peserta didik merasa sangat senang terhadap penggunaan media Tabel Andromatika, yakni mencapai 18 peserta didik atau sekitar 69,2\%. Mereka merasa lebih mudah dan lebih nyaman menggunakan media. Mereka tidak usah membuat garis-garis yang cukup menyita waktu dan gambarnya tidak membosankan. Kemudian soal dibuat lebih interaktif sehingga peserta didik mengetahui jawabannya apakah benar atau salah. Dan yang terakhir bagian game edukasi sangat menyenangkan karena disamping bermain game, peserta didik juga diajak untuk belajar. Mereka sangat senang dalam menyelesaikan misi game yang dibubuhi dengan soal tentang FPB dan KPK. Sedangkan beberapa peserta didik merasa senang terhadap penerapan media Tabel Andromatika karena tidak 
terlalu banyak catatan ataupun coretan ketika mengerjakan soal tentang FPB dan KPK, yakni mencapai 6 peserta didik atau sekitar 23,1\%. Mereka beranggapan kadang merasa agak malas ketika harus membuat tabel terlebih dahulu, sehingga menyita banyak waktu dan pengerjaan soal pun akan menjadi lebih lama. Namun, ada 2 peserta didik yang merasa tidak senang menggunakan Tabel Andromatika dengan alasan ia masih suka menggunakan cara lama, yakni pohon faktor. Sedangkan 1 peserta didik lainnya karena ia masih belum mahir dalam berhitung sehingga ia tidak menggunakan media dengan baik.

\section{Penutup}

Penerapan Guided Discovery Learning dengan media Tabel Andromatika berimbas pada peningkatan motivasi belajar. Hal demikian dapat ditelaah pada hasil angket ARCS yang telah diisi oleh peserta didik yakni rata-rata rentang nilai 4,63 dengan kategori sangat baik. Adapun rinciannya meliputi kondisi perhatian, percaya diri, dan kepuasan berkategori sangat baik sedangkan kondisi relevansi berkategori baik. Selain itu, peningkatan hasil belajar sebagai salah satu indikator keberhasilan penerapan Guided Discovery Learning dengan media Tabel Andromatika. Meningkatnya hasil belajar peserta didik dapat ditelaah pada pada hasil evaluasi yang dilakukan oleh peneliti dengan ketuntasan belajar mencapai 96,15\% dengan rincian 25 peserta didik telah tuntas dalam belajar sedangkan 1 peserta didik belum tuntas belajar. Adapun rata-rata nilai kelas mencapai 89,62 . Selain peningkatan motivasi dan hasil belajar, pemanfaatan Tabel Andromatika yang diterapkan pada Guided Discovery Learning juga dapat mengembangkan karakter peserta didik meliputi gotong royong, mandiri, dan integritas.

\section{Ucapan Terima Kasih}

Penulis mengucapkan terima kasih kepada pihak yang telah membantu terutama kepada kepala sekolah SDN Kaliwlingi 02 Kabupaten Brebes yang telah memberikan ijin penelitian. Ucapan terima kasih juga penulis sampaikan pada Bapak/Ibu guru dan peserta didik SDN Kaliwlingi 02. 
Paling utama ucapan terima kasih kepada Subdit Kesharlindungdikdas Direktorat Pembinaan Guru Pendidikan Dasar Direktorat Jenderal Guru dan Tenaga Kependidikan Kementerian Pendidikan dan Kebudayaan yang telah memberikan bimbingan dan fasilitasi dalam penulisan artikel jurnal ini. Selain itu, ucapan terima kasih juga disampaikan kepada tim editor Jurnal Didaktika Pendidikan Dasar yang telah memberikan koreksi dan masukannya sehingga artikel ini dapat diterbitkan.

\section{Daftar Referensi}

Astawa, I Gusti Lanang Gede Putra. 2018. Pembelajaran Temuan Terbimbing Berbantuan Manik Android Motivasi dan Hasil belajar Operasi Hitung Bilangan Bulat. Jurnal Dikdaktika Pendidikan Dasar Volume 2 Nomor 2 Tahun 2018: 73-87.

Eggen dan Kauchak. 2012. Strategi dan Model Pembelajaran (Edisi ke-6). Jakarta: Indeks.

Kemdikbud. 2013. Permendikbud Nomor 22 Tahun 2016 tentang Standar Proses Pendidikan Dasar dan Menengah. Jakarta : Kementerian Pendidikan dan Kebudayaan.

Markaban. 2008. Model Penemuan Terbimbing Pada Pembelajaran Matematika. Yogyakarta: Depdiknas PPTKM.

Muhsetyo, Gatot dkk. 2009. Pembelajaran Matematika SD (Edisi Ke-1). Jakarta: Universitas Terbuka.

Rusman. 2012. Belajar dan Pembelajaran Berbasis Komputer, Mengembangkan Profesionalisme Guru Abad 21. Bandung: Alfabeta.

Sumaiati dan Asra. 2008. Metode Pembelajaran. Bandung: CV Wacana Prima.

Sya'roni, Ach. Reno \& Ria Amalia. 2016. Pengembangan Program Aplikasi Mathematics Mobile Learning Berbasis Android Sebagai Media Pembelajaran Matematika Wajib Kelas X Sekolah Menengah Atas. Jurnal Edukasi Matematika EDUMAT. Volume 7 November 2016: 799-807.

Thiagarajan, Sivasailam, Semmel, Dorothy S \& Semmel, Melvyn I. 1974. Instructional Development for Training Teachers of Expectional Children. Minneapolis, Minnesota: leadership training instirute/special Education, University of Minnesota. 
Trianto. 2010. Mendesain Model Pembelajaran Inovatif-Progres. Jakarta: Jaka Kencana.

Wahidmurni dkk. 2010. Evaluasi Pembelajaran Kompetensi dan Praktek. Yogyakarta: Nuha Litera.

Wirawan, W.W., Sulastri, Md.,Suarjana, I Md. 2013. Meningkatkan Motivasi dan Hasil Belajar IPA Melalui Penerapan Quantum Teaching pada Siswa Kelas V Semester II Tahun Pelajaran 2011/2012 di SDN 1 Negari, Jurnal Undiksha, 1-11.

Yazdani, K \& Godbole, V.S. 2014. Studying Teh Role of Habbitscand Achievement Motivation in Improving Students Acaemic Performance. European Online Journal of Natural and Social Sciences, 3, (4), 827830. 